\title{
A liquidez das relações socioculturais na contemporaneidade: os paradoxos trazidos à baila pela pandemia do novo Coronavírus
}

\author{
The liquidity of sociocultural relations in contemporary times:
} the paradoxes brought up by the new Coronavirus pandemic

Daniel Cardoso Alves ${ }^{1}$

1 Doutorando em Educação pela FaE/UFMG. Mestre em Ciências Ambientais, Especialista em Análise do Espaço Geográfico, Licenciado em Geografia pela UESB/BA. Professor de Estudos Filosóficos da FaE/UEMG.

E-mail: dca.uemg@gmail.com Orcid: http://orcid.org/0000-0002-1597-5180 Lattes: http://lattes.cnpq.br/1618004302770371

RESUMO: Este artigo aborda sobre as clássicas concepções do atual modelo de sociedade em meio a um contexto de pandemia viral. Para tanto, a questão que o permeia é a seguinte: O que caracteriza uma "sociedade em rede" alterada pelo "meio técnico-científico-informacional" e imersa numa "modernidade líquida"? Essa abordagem, sobretudo num latente contexto de crises, revela-se imprescindível para a compreensão do que venha a ser progresso na sociedade contemporânea. Adotando como pano de fundo o contexto da pandemia do novo Coronavírus no Brasil, objetiva-se desvelar os paradoxos desse modelo de sociedade. O artigo caracteriza-se metodologicamente como uma revisão de literatura que traz à tona reversos de uma "modernidade líquida". Para tanto, ancora-se em fundamentos filosóficos, históricos, geográficos e socioculturais que envolvem o tema. Como principais resultados, evidencia que diante do contexto pandêmico, adotado como caso empírico de análise, se faz necessário: (re)pensar os atributos inerentes a uma "modernidade líquida", os quais, paradoxalmente, estão vinculados à noção daquilo que se idealizou por chamar de progresso e/ou visão de futuro; desvelar a falsa consciência de seres autossuficientes e a importância que possui o sentimento de alteridade em qualquer sociedade; e romper com a ilusão de que o homem é, em si, o único responsável por sua própria existência. Conclui-se defendendo uma complementariedade entre a sentença aristotélica sobre a natureza social humana e os postulados hegelianos acerca da ontologia do Ser.

Palavras-chave: Pandemia. Paradoxos. Sociedade contemporânea.

ABSTRACT: This article deals with the classic conceptions of the current model of society in the context of a viral pandemic. Therefore, the question that permeates it is the following: What characterizes a "network society" altered by the "technical-scientific-informational medium" and immersed in a "liquid modernity"? This approach, especially in a latent context of crises, proves to be essential to understand what may be progress in contemporary society. Adopting the context of the pandemic of the new Coronavirus in Brazil as a backdrop, the objective is to unveil the paradoxes of this model of society. It article is characterized methodologically as a literature review that brings up the paradoxes of a "liquid modernity". Therefore, it is based on philosophical, historical, geographic and sociocultural foundations that involve the theme. As main results show, in a pandemic context, adopted as an empirical case of analysis, it is necessary: (re) thinking about the attributes inherent to a "liquid modernity", which, paradoxically, are linked to the notion of what was idealized by calling progress and / or vision of the future; unveiling the false awareness of self-sufficient beings and the importance of the feeling of otherness in any society; and break with the illusion that man is, in itself, solely responsible for his own existence. It concludes by defending a complementarity between the Aristotelian sentence on human social nature and the Hegelian postulates about the ontology of Being. 


\section{Keywords: Pandemic. Paradoxes. Contemporary society.}

\section{Para um início de conversa}

Homo est animal sociale - esta é a sentença originária de Aristóteles que, em geral, conhecemos pela expressão "somos seres sociais por natureza", visto que, em português, traduz-se em "o homem é um animal social".

Segundo Arendt (2001), essa natureza social do homem justifica-se na relação entre ação e vida em comum, sendo aceita, inclusive, por filósofos estóicos e escolásticos, a exemplo de Sêneca e Tomás de Aquino, respectivamente.

Aquino, de acordo com Arendt (2001), assim traduzia a supracitada sentença aristotélica: Homo est naturaliter politicus, id est, socialis, ou seja, "o homem é, por natureza, político, isto é, social”.

A intenção de recuperar essa sentença, neste início de conversa, reside no fato de que o mundo esteja vivendo, no ano de 2020, um período com raros precedentes na sua história, em que palavras como Coronavírus SARS-CoV-2, Covid-19, pandemia, solastalgia, quarentena, empatia, isolamento, assepsia, evitação social, entre tantas outras correlacionadas, nunca estiveram tão presentes no vocabulário cotidiano das pessoas como agora, vocábulos esses que remetem, prioritariamente, à natureza social de ser humano, amplamente abordada não apenas por Aristóteles e Aquino, mas também por outros filósofos e estudiosos clássicos, medievais, modernos e contemporâneos.

Em relação aos citados vocábulos, o que intriga é a constatação de que, apesar de muitos deles serem produtos do modelo ideal de sociedade integrada, instantânea, tecnológica, fluida e propiciadora de um novo ser social, o ser tecnológico, pelo qual a humanidade, há séculos, vem se empenhando a atingir, passam, paradoxalmente, a representar, no momento atual, uma dificuldade na "sociedade em rede".

Não seriam essas expressões consequências inevitáveis da busca por uma modernidade que, segundo Bauman (2001), caracteriza-se pela liquidez das relações sociais e dos modos de vida?

Então porque o estranhamento em relação a contextos ${ }^{1}$ isolacionistas e pandêmicos numa "sociedade em rede", em que os contatos são virtuais e a conexão entre os seres, e tudo aquilo que os cerca, se dá pela velocidade máxima de fibras ópticas, em rede, desafiando barreiras e fronteiras físicas, culturais, econômicas, políticas, históricas e ambientais?

Esses questionamentos, no mínimo, desvelam a existência de um paradoxo, visto que, quando consideramos que a humanidade ao pautar a busca por aquilo que um dia ela denominou progresso na construção de sociedades fluidas, tecnológicas, desterritorializadas e glocais, o que impactou nas relações sociais e nos modos de vida, distanciou-se do princípio originário da singularidade que define o homem, a sua natureza social, a sua necessidade de grupo. Contudo, esclarece o filósofo e sociólogo alemão Habermas (1968) que:

os interesses sociais continuam a determinar a direção, as funções e a velocidade do progresso técnico. Mas tais interesses definem de tal modo o sistema social como um todo, que coincidem com o interesse pela manutenção do sistema. A forma privada da revalorização do capital e a chave de distribuição das compensações sociais, que garantem a lealdade da população, permanecem como tais subtraídas à discussão. Como variável independente, aparece então um progresso quase autônomo da ciência e da

\footnotetext{
${ }^{1}$ Contexto, assim como a Cultura, nunca é fixo e restrito. É sempre amplo, dinâmico e em construção. Tomado de forma isolada, ele perde o seu dinamismo e torna-se uma palavra sem ação e conteúdo.
} 
técnica, do qual depende de facto a outra variável mais importante do sistema, a saber, o crescimento econômico. Cria-se assim uma perspectiva na qual a evolução do sistema social parece estar determinada pela lógica do progresso técnico-científico. A legalidade imanente de tal progresso parece produzir as coações materiais pelas quais se deve pautar uma política que se submete às necessidades funcionais (p. 73).

O distanciamento do sujeito da sua singularidade humana encontra associações com a construção de uma ideia de progresso que, segundo Habermas (1968), foi sendo institucionalizada sob o crivo da racionalidade ${ }^{2}$ técnica e científica. Essa racionalidade impregnou as esferas sociais e suas instituições, desmoronando tradicionais legitimações, a exemplo da singular natureza social do homem, que estavam, até então, culturalmente consolidadas.

Como esclarece Habermas (1968), essa racionalidade é medida

pela manutenção de um sistema que pode permitir-se converter em fundamento da sua legitimação do incremento das forças produtivas associado ao progresso técnico-cientifico, embora, por outro lado, o estado das forças produtivas represente precisamente também o potencial, pelo qual medidas «as renuncias e as incomodidades impostas aos indivíduos estas surgem cada vez mais como desnecessárias e irracionais (p. 47).

Com isso, nesse momento de pandemia viral, a solastalgia surge como um sentimento paradoxal que, nas palavras de Habermas (1968, p. 46), poderíamos traduzi-la como o "[...] reverso de uma «racionalidade» crescente da ação social”, uma necessidade de emancipação da dominação técnico-científica que prevalece entre as pessoas da sociedade do progresso, em rede, as quais, dias atrás, guiadas pela dominação imposta por essa racionalidade, privilegiavam as relações virtuais. Essas pessoas, como que numa situação de guerra, passam a sofrer por se sentirem obrigadas à privação do convívio sócio físico, o qual, até pouco tempo, era natural e inconscientemente substituído pelo convívio sócio virtual.

De fato, a solastalgia do ser, entendida como paradoxo do progresso, cresce na proporção que o temor de contaminação por uma doença, a Covid-19, aumenta, se dissemina e se populariza no campo técnico-científico, mas, também, no ideológico. Doença que, segundo a Organização Mundial de Saúde (OMS), está relacionada a

[...] uma série de investigações detalhadas (que) descobriram que o SARS-CoV foi transmitido de civetas para humanos na China em 2002 e o MERS-CoV de camelos dromedários para humanos na Arábia Saudita em 2012. Vários coronavírus conhecidos estão circulando em animais que ainda não infectaram humanos. À medida que a vigilância melhora no mundo, é provável que mais coronavírus sejam identificados [...]. Estudos até o momento sugerem que o vírus causador da COVID-19 pode se propagar de pessoa para pessoa por meio de gotículas do nariz ou da boca que se espalham quando uma pessoa com COVID-19 tosse ou espirra. A maioria dessas gotículas cai em superfícies e objetos próximos - como mesas ou telefones. As pessoas também podem pegar COVID-19 se respirarem gotículas de uma pessoa com COVID-19 que tosse ou espirra. E por isso que é importante ficar a mais de 1 metro (3 pés) de uma pessoa doente [...] (OMS, 2020).

Assim como a OMS, médicos infectologistas esclarecem que por se tratar de uma doença de fácil

2 "Max Weber introduziu o conceito de "racionalidade" para definir a forma da actividade econômica capitalista, do trafego social regido pelo direito privado burguês e da dominação burocrática. Racionalização significa, em primeiro lugar, a ampliação das esferas sociais, que ficam submetidas aos critérios da decisão racional" (HABERMAS, 1968, p. 45). 
contágio, com inexistência de vacinas preventivas e por ter um grau de letalidade significativo pincipalmente entre pessoas idosas e com comorbidades patogênicas como diabetes, doenças cardíacas e pulmonares, as medidas mais eficazes de evitar a sua disseminação são o isolamento social e, em casos de pessoas potencial e/ou efetivamente contaminadas, a quarentena.

Em cumprimento a essas recomendações, governos federais, estaduais e municipais mundo afora têm decretado medidas que levem à efetividade desse isolamento, restando aos seres virtuais das sociedades do progresso contentarem-se com as relações fluidas, mediadas pela tecnologia, criadas e tão valorizadas por eles.

No contexto brasileiro, essas medidas têm se enfraquecido diante de crises outras. Em meio à pandemia e ao aumento expressivo do número de óbitos e casos de pessoas contaminadas pela Covid-19 no Brasil, o país passou por trocas de ministros da saúde, da justiça, da educação e vem convivendo com discursos pautados em disputas e crises políticas e econômicas, agravadas por declarações e posturas polêmicas por parte do presidente da república, o que acaba por tergiversar os esforços que deveriam estar concentrados no controle da crise sanitária em si.

Durante a entrevista, uma jornalista disse ao presidente: "A gente ultrapassou o número de mortos da China por covid-19". O presidente, então, afirmou:

"E daí? Lamento. Quer que eu faça o quê? Eu sou Messias, mas não faço milagre", disse, em referência ao próprio sobrenome.

Momentos depois, na mesma entrevista, Bolsonaro disse se solidarizar com as famílias das vítimas. "Lamento a situação que nós atravessamos com o vírus. Nos solidarizamos com as famílias que perderam seus entes queridos, que a grande parte eram pessoas idosas", disse.

"Mas é a vida. Amanhã vou eu. Logicamente, a gente quer ter uma morte digna e deixar uma boa história para trás", disse o presidente (PORTAL DE NOTÍCIAS G1, 2020).

A respeito desses embates no campo científico e político-ideológico ilustrado pela oposição discursiva entre o que defende, de um lado, a OMS, as autoridades de saúde no Brasil e os médicos especialistas e, do outro, o que declara o presidente da nação brasileira, faz-se necessário recorrermos à diferenciação estabelecida pelo filósofo político francês Lyotard (2004), a fim de compreendermos a natureza desse conflito discursivo.

Segundo Lyotard (2004, p. 12), o saber total se constitui de suas dimensões científica e narrativa. Constituído por essas duas dimensões, o saber em sua totalidade é sempre científico e narrativo. Dessa forma, apreende-se que "o saber científico não é todo o saber; ele sempre esteve ligado a seu conceito, em competição com uma outra espécie de saber que [...] chamaremos de narrativo", usualmente confundido com a ideia de saber fictício.

Entretanto, como explica o filósofo, qualquer que seja o saber, a dimensão narrativa lhe é inerente, sendo que a sua credibilidade está associada a um viés ora especulativo, ora emancipatório. Enquanto saber construído sob uma narrativa especulativa, há uma priorização da acumulação do conhecimento que o reduz a um fim em si mesmo, ao passo que, enquanto produto de uma narrativa de emancipação, nota-se uma apropriação do saber como meio para a libertação da consciência humana, o que contribui para emancipála de discursos dogmáticos, míticos e dominadores.

A despeito dessa divisão, Lyotard (2004, p. 69) esclarece que "na sociedade e na cultura contemporânea [...] a questão da legitimação do saber coloca-se em outros termos. A grande narrativa perdeu sua credibilidade, seja qual for o modo de unificação que lhe é conferido: narrativa especulativa, narrativa de emancipação". 
Com base nesse esclarecimento, entendemos que o discurso sustentado pela OMS, pelas autoridades de saúde no Brasil e pelos médicos especialistas decorreria de um saber científico construído a partir de uma narrativa não exclusivamente emancipatória, assim como o discurso proferido pelo presidente do Brasil que, apesar de não se constituir como um saber científico, resultaria numa perspectiva também não exclusivamente emancipatória. Todavia, o discurso do presidente brasileiro estaria, de forma mais latente, impregnado de poder e ideologia, o que, segundo Lyotard (2004, p. 112), "desestabiliza a capacidade de explicação" do discurso. Ou seja, enquanto a OMS, as autoridades de saúde no Brasil e os médicos especialistas estariam comprometidos com uma narrativa de saber mais emancipatória, o presidente brasileiro estaria comprometido com uma narrativa mais especulativa. De toda forma, não se pode desconsiderar que o poder e a ideologia atravessam ambas narrativas.

Assim, o objetivo deste artigo não é condenar essas sociedades do progresso, até porque foi devido às suas capacidades tecnológicas e de inventividade científica que a humanidade superou situações caóticas de outros contextos críticos e assim avançou, nem tão pouco tergiversar no debate político buscando provar o discurso verdadeiro, pois sabemos que ele inexiste em sua totalidade radical, mas sua intenção é desvelar os paradoxos de uma "sociedade em rede" alterada pelo "meio técnico-científico-informacional" e imersa numa "modernidade líquida", cuja cultura digital não se resume à ideologização da técnica e não substitui a característica humana de ser social, ou seja, não substitui as subjetividades e necessidades humanas, que são os motores para a produção cultural de um povo.

Com esse objetivo, será explorada a concepção paradoxal de "sociedade em rede" alterada pelo "meio técnico-científico-informacional" e imersa num contexto de "modernidade líquida", valendo-se, para tanto, dos postulados teóricos de Aristóteles (1982), Bauman (2001), Bottomore (1998), Castells (1999), Giddens (1995), Habermas (1968), Hegel (1992), Jenkins (2009), Lefebvre (1985), Levy (2000), Lyotard (2004), Pinto (2005) e Santos $(1997 ; 2008 ; 2009)$. A partir desses pressupostos teóricos, problematizaremos sobre as mazelas sociais, histórias, culturais, políticas, econômicas, ambientais, científicas e tecnológicas no contexto da pandemia do novo Coronavírus vivenciado no Brasil. Concluiremos pretendendo uma aproximação, ainda que paradoxal, entre a sentença aristotélica de natureza social humana e os postulados hegelianos acerca da ontologia do ser, visto que, o que mais enriquece o saber é o diálogo confrontado com a finalidade de se alcançar as convergências possíveis e não, meramente, o acirramento de ideias. Essa aproximação caminha na direção da ressignificação do que se entende por progresso num cenário de pandemia viral que aflige a humanidade na contemporaneidade.

\section{O que caracteriza uma "sociedade em rede" alterada pelo "meio técnico- científico-informacional" e imersa numa "modernidade líquida"?}

Para Bauman (2001), sociólogo polonês, uma sociedade num contexto de "modernidade líquida" tem como característica elementar a existência de um novo ser social: usuário de tecnologias, intercultural, integrado, instantâneo e fluido.

Esse novo ser social do século XXI, nas palavras do sociólogo, é o construtor dos aparatos que sustentam uma "modernidade líquida", apropriada como um não-lugar ${ }^{3}$ necessário para que os fluidos se movimentem facilmente, para que eles

3 Lefebvre (1985, p. 152), entende que os lugares "Tanto se opõem como se completam ou se reúnem [...], mas também e, sobretudo, uma oposição altamente pertinente entre os espaços dominados e apropriados". 
[...] 'escorrem', 'esvaem-se', 'respingam', 'transbordam', 'vazam', 'inundam', 'borrifam', 'pingam', são 'filtrados', 'destilados'; diferentemente dos sólidos, não (que) são facilmente contidos - contornam certos obstáculos, dissolvem outros e invadem ou inundam seu caminho... Associamos 'leveza' ou 'ausência de peso' à mobilidade e à inconstância: sabemos pela prática que quanto mais leves viajamos, com maior facilidade e rapidez nos movemos (BAUMAN, 2001, p. 8).

Em entrevista à Revista Isto é, ao ser questionado sobre a consciência das pessoas em relação ao estágio líquido da modernidade que se encontra a sociedade, o autor declarou que

[...] todos estamos cientes disso, num grau ou outro. Pelo menos às vezes, quando uma catástrofe, natural ou provocada pelo homem, torna impossível ignorar as falhas. Portanto, não é uma questão de "abrir os olhos". O verdadeiro problema é: quem é capaz de fazer o que deve ser feito para evitar o desastre que já podemos prever? O problema não é a nossa falta de conhecimento, mas a falta de um agente capaz de fazer o que o conhecimento nos diz ser necessário fazer, e urgentemente. Por exemplo: estamos todos conscientes das consequências apocalípticas do aquecimento do planeta. E todos estamos conscientes de que os recursos planetários serão incapazes de sustentar a nossa filosofia e prática de "crescimento econômico infinito" e de crescimento infinito do consumo. Sabemos que esses recursos estão rapidamente se aproximando de seu esgotamento. Estamos conscientes — mas e daí? Há poucos (ou nenhum) sinais de que, de própria vontade, estamos caminhando para mudar as formas de vida que estão na origem de todos esses problemas (PRADO, Isto é, 2003).

Bauman (2003) entende que vivemos uma "modernidade líquida" porque, assim como líquidos, estamos mudando "de forma muito rapidamente, sob a menor pressão [...]. No atual estágio "líquido" da modernidade, os líquidos são deliberadamente impedidos de se solidificarem [...] (PRADO, Isto é, 2003).

Nessa mesma direção, Castells (1999, p. 497), ao valer-se da expressão “sociedade em rede", explica que essa "nova morfologia social de nossas sociedades, e a difusão da lógica de redes modifica, deforma substancialmente a operação e os resultados dos processos produtivos e de experiência, poder e cultura". Nas palavras desse sociólogo espanhol:

O tempo intemporal parece ser o resultado da negação do tempo - passado e futuro - nas redes do espaço de fluxos. Enquanto isso, o tempo cronológico, medido e avaliado diferencialmente para cada processo de acordo com sua posição na rede, continua a caracterizar as funções subordinadas e os locais específicos. O fim da história, estabelecido na circularidade dos fluxos financeiros computadorizados ou na instantaneidade das guerras cirúrgicas, domina o tempo biológico da pobreza ou o tempo mecânico do trabalho industrial. A construção social das novas formas dominantes de espaço e tempo desenvolve uma meta-rede que ignora as funções não essenciais, os grupos sociais subordinados e os territórios desvalorizados. Com isso, gera-se uma distância social infinita entre essa meta-rede e a maioria das pessoas, atividades e locais do mundo. Não que as pessoas, locais e atividades desapareçam. Mas seu sentido estrutural deixa de existir, incluído na lógica invisível da meta-rede em que se produz valor, criam-se códigos culturais e decide-se o poder. Cada vez mais, a nova ordem social, a sociedade em rede, parece uma meta-desordem social para a maior parte das pessoas. Ou seja, uma sequência automática e aleatória de eventos, derivada da lógica incontrolável dos mercados, tecnologia, ordem geográfica ou determinação biológica (CASTELLS, 1999, p. 505).

Diante de uma "modernidade líquida" e de uma "sociedade em rede", Santos (2009), consagrado geógrafo brasileiro, em sua abordagem sobre o "meio técnico-científico-informacional” esclarece que, inevitavelmente, nossa sociedade encontra-se dominada por esse meio que 
[...] é marcado pela presença da ciência e técnica nos processos de remodelação dos territórios essenciais às produções hegemônicas, que necessitam desse novo meio geográfico para sua realização. A informação, em todas as suas formas, é o motor fundamental do processo social e o território é, também, equipado para facilitar a sua circulação (SANTOS, 2009, p. 38).

Segundo Santos (2008, p. 46-47), a “instantaneidade da informação globalizada aproxima os lugares, torna possível uma tomada de conhecimento imediata de acontecimentos simultâneos e cria, entre lugares e acontecimentos, uma relação unitária na escala do mundo", o que se traduz num modelo de sociedade dominada pela técnica, ciência e informação.

Para garantir essa relação, Santos (1997, p. 238) entende que a tecnologia vem se constituindo "não apenas uma esfera da realidade, mas uma ordem da realidade, possuidora de sua própria racionalidade [...]. As inovações técnicas se encontram com a história portando suas próprias regras, às quais as demais escolhas devem curvar-se".

Comungando também de uma concepção marxista dialética, entendemos tecnologia como

[...] produto: artefatos que encerram valor e têm valor de uso (...) Marx ressalta que é a tecnologia, e não a natureza, que tem importância fundamental: "a natureza não fabrica máquinas, locomotivas, ferrovias, telégrafo elétrico, máquina de fiar automática, etc. Tais coisas são produtos da indústria humana; material natural transformado em órgãos da vontade humana que se exerce sobre a natureza ou da participação humana na natureza. São órgãos do cérebro humano, criados pela mão humana: o poder do conhecimento objetificado (GRUNDRISSE apud BOTTO-MORE, 1998, p. 371).

Pinto (2005), filósofo brasileiro contemporâneo, entende que há predominância de uma concepção de tecnologia como sinônimo de técnica ideologizada. Para o filósofo, a lógica tecnocêntrica prevalece no conceito de tecnologia na tentativa de supervalorizá-la como técnica dominadora. Todavia, essa ideologização conceitual assume uma dimensão heurística fundamental para a relação entre tecnologia e cultura, visto que, enquanto produto cultural

A técnica, na qualidade de ato produtivo, dá origem a considerações teóricas que justificam a instituição de um setor do conhecimento, tomando-a por objeto e sobre ela edificando as reflexões sugeridas pela consciência que reflete criticamente o estado do processo objetivo, chegando ao nível da teorização. Há sem dúvida uma ciência da técnica, enquanto fato concreto e por isso objeto de indagação epistemológica. Tal ciência admite ser chamada de tecnologia (PINTO, 2005, p. 220).

Levy (2000), filósofo e sociólogo francês, destaca em sua abordagem sobre a virtualização da comunicação que, nessa sociedade dominada pelo "meio técnico-científico-informacional”, o modo de se comunicar e interagir entre as pessoas ganhou uma nova roupagem: a tecnologia.

Marcada por essa vestimenta tecnológica, a sociedade atual se apresenta geográfica e culturalmente informacional, cujas relações sociais passam a ser virtualizadas. Contudo, essa virtualização das relações humanas, segundo Levy (2000, p. 90), “não substitui o real [...]”, não exclui a necessidade humana por "[...] contatos em carne e osso” (LEVY, 2000, p. 107), visto que a virtualização das relações sociais apenas atualiza e potencializa as necessidades humanas por contatos reais.

Nesse sentido, ainda que por caminhos virtuais, a necessidade por interação humana sempre estará acima das formas, as quais, tão somente, facilitam a convergência e transformam tecnologicamente em materialidades necessidades diversas, o que inclui as trocas sociais. Essas necessidades virtualizadas, apesar de deixarem de ter um referencial espacial, não sucumbem com aquilo que vem a priori e integra a essência de 
ser humano: a necessidade de interdependência entre os sujeitos nos seus processos relacionais.

A inexistência desse referencial espacial é denominada por Levy (2000) como ciberespaço, onde se combinam vários modos de comunicação, por meio dos quais as pessoas passam a ser contatadas "[...] não mais em função de seu nome ou de sua posição geográfica, mas a partir dos centros de interesse” (LEVY, 2000, p. 103).

Ou seja, assim como as interações tornam-se fluidas, o espaço também deixa de ter fronteiras físicas, passando à categoria geográfica de Rede; as distâncias são, ainda que tecnologicamente, encurtadas, pelo que, ninguém escapa dos novos padrões que se traduzem na cibercultura de uma "sociedade em rede" alterada por um "meio técnico-científico-informacional" e imersa numa "modernidade líquida".

Essa cibercultura tem como característica a cultura da convergência que, segundo Jenkins (2009), estudioso norte-americano que integra o rol de pesquisadores sobre mídia e considerado um dos mais influentes da atualidade, é marcada pela cultura participativa e inteligência coletiva.

No que concerne à convergência, o autor entende que a ela associam-se transformações tecnológicas, mercadológicas, culturais e sociais. Essa cadeia de transformações “' [...] não é algo que vai acontecer um dia, quando tivermos banda larga suficiente ou quando descobrirmos a configuração correta dos aparelhos. Prontos ou não, já estamos vivendo uma cultura da convergência” (JENKINS, 2009, p. 43), que:

[...] não envolve apenas materiais e serviços produzidos comercialmente, circulando por circuitos regulados e previsíveis. Não envolve apenas as reuniões entre empresas de telefonia celular e produtoras de cinema para decidirem quando e onde vamos assistir à estreia de um filme. A convergência também ocorre quando as pessoas assumem o controle das mídias. Entretenimento não é a única coisa que flui pelas múltiplas plataformas de mídia. Nossa vida, nossos relacionamentos, memórias, fantasias e desejos também fluem pelos canais de mídia. Ser amante, mãe ou professor ocorre em plataformas múltiplas (JENKINS, 2009, p. 45).

Em outras palavras, seria essa cultura da convergência uma espécie de conjunto de elementos em que se intercruzam transformações tecnológicas e mercadológicas conduzidas pelo fator sociocultural.

Nesse intercruzamento técnico-mercadológico, à consciência da dominação tecnológica sobre nossas relações sociais e nossos modos de vida precede a autoconsciência que, segundo Habermas (1968), resulta

da auto experiência do sujeito cognoscente, que abstrai de todos os objectos possíveis no mundo e se volta para si como único objecto. A subjetividade do Eu está determinada como reflexão - ela é a relação consigo mesmo, própria do sujeito que a si mesmo se sabe. Nela se estabelece a unidade do sujeito como autoconsciência (p. 14)

No entanto, essa dominação, compartilhando das reflexões de Santos (1997; 2008; 2009) e Pinto (2005), não se dá pela técnica, visto que, ela é um produto sociocultural, ou seja, estamos diante de uma dominação cultural que se apresenta nesse contexto espaço-temporal sob uma forma tecnológica que emana poder e cultura, afetando tudo aquilo que somos e que nos cerca, inclusive a nossa autoconsciência construída dialeticamente e que, segundo Habermas (1968):

[...] já não figura como originaria. Para Hegel, resulta antes da experiência da interação, em que Eu aprendo a ver-me com os olhos do outro sujeito. A consciência de mim mesmo deriva de um entrelaçamento das perspectivas. Só com base no reconhecimento reciproco se forma a autoconsciência, que se deve fixar no reflexo de mim mesmo na consciência de um outro sujeito (p. 15). 
Por isso, a tecnologia não nega a nossa ontologia de ser, a nossa essência humana, a nossa natureza social logicamente provada por Aristóteles (1982) ou fenomenologicamente pressuposta por Hegel (1992), ela é produto de uma consciência que "[...] existe como um meio em que os sujeitos se encontram, de tal modo que, sem se encontrarem, não poderiam existir como sujeitos” (HABERMAS, 1968, p. 15).

Enfim, somos seres sociais paradoxais por natureza, seja pela via lógica, haja vista que "as primeiras uniões entre pessoas, oriundas de uma necessidade natural, são aquelas entre seres incapazes de existir um sem o outro [...]" (ARISTOTE, 1982, 1253b, p. 13-14), seja pela via fenomenológica, posto que "um ser determinado, finito, é um ser tal que se refere a outro; é um conteúdo que está em uma relação de necessidade com outro conteúdo, com o mundo inteiro [...]” (HEGEL, 1992, p. 112-113).

O que constatamos é que em todas as supracitadas abordagens não é negada a necessidade humana de interação social, visto que, com ou sem tecnologia, independente de uma "modernidade líquida" alterada por um "meio técnico-científico-informacional”, o homem, enquanto animal social por natureza lógica e/ou fenomenológica, sempre buscará formas para atender a essa sua necessidade que, assim como as materialidades resultantes, está em constante processo de metamorfose.

É certo que há uma supervalorização da cultura tecnológica inerente à "sociedade em rede". Conforme Nietzsche (1999):

Pode-se muito bem, aqui, admirar o homem como um poderoso gênio construtivo, que consegue erigir sobre fundamentos móveis e como que sobre água corrente um domo conceitual infinitamente complicado: - sem dúvida, para encontrar apoio sobre tais fundamentos, tem de ser uma construção como que de fios de aranha, tênue a ponto de ser carregada pelas ondas, firme a ponto de não ser espedaçada pelo sopro de cada vento (p. 58).

Contudo, como se apreende das palavras de Nietzsche (1999) que quem produz essa genialidade é o homem, pelo que, as materialidades (o que inclui a tecnologia) só existem porque decorreram de uma necessidade que o levou a criá-las. Essas materialidades, tecnológicas ou não, que afetam a consciência do sujeito, seus modos de vida e suas relações sócio espaciais, não são as criadoras, mas sim as criaturas culturais, visto que provêm da necessidade humana de produzir linguagem, conceito, pensamento e virtualidade, necessidade essa que é produtora de cultura.

Portanto, evidenciar a compreensão de que o mundo é um produto sociocultural, sobretudo num contexto contemporâneo marcado por um aparelhamento ideológico empenhado na subjugação dos desejos humanos e na "[...] autocoisificação dos homens, sob as categorias da acção racional dirigida a um comportamento adaptativo" (HABERMAS, 1968, p. 74), significa libertar o sujeito das amarras que impedem a tomada da sua autoconsciência, bem como, reafirma a cultura como criação humana.

\section{Os paradoxos trazidos à baila pela pandemia do novo Coronavírus}

\section{O mundo parou!}

Essa foi uma das frases mais repetidas no início da segunda década do século XXI em referência aos efeitos provocados pela pandemia do novo Coronavírus, causador da doença Covid-19. O temor pela disseminação do novo Coronavírus resultou em medidas que abalaram o sistema econômico de grandes potências e desvelou a fragilidade dos sistemas de saúde, a interdependência política e econômica entre seres e nações, bem como, a toxidade das relações humanas.

A incerteza sobre o que seria essa doença e os impactos que ocasionariam com a execução das 
medidas mais eficazes (estratégias de isolamento social, quarentena, uso universal de máscaras para a proteção do sistema respiratório e a intensificação de hábitos de higiene) para evitar a sua propagação e, ao mesmo tempo, estratégias de difícil controle, tomou a cena dos noticiários e do cotidiano das pessoas em todo o mundo.

O epicentro dessa doença foi a cidade chinesa de Wuhan, a mais populosa na região central do país com 11 milhões de habitantes. Em poucos dias o número de chineses infectados escalou, o número de mortes aumentou e instantaneamente o novo Coronavírus atravessou fronteiras para além do continente asiático, atingindo inicialmente a Europa e se alastrando por todos os outros quatro continentes do planeta. Diante da rapidez com que o vírus se espalhava, caracterizando uma situação de pandemia, a OMS, apesar de ter retardado, acabou declarando situação de emergência internacional.

No mundo, especialmente na China, governos operavam em medida de emergência decretando situação de calamidade pública e estabelecendo estratégias de combate ao contágio, dentre as quais, a interrupção e/ou redução de serviços e lazer como forma de garantir a efetividade do isolamento social, principal medida de controle da disseminação da doença. Não demorou muito e essas estratégias impactaram a economia mundial.

No Brasil, o governo executivo federal, até enquanto pôde, relutou em adotar essas medidas, definindo inicialmente a situação no país como perigo iminente, o que foi acompanhado de declarações polêmicas por parte do presidente da república, sujeito do qual esperava-se, de acordo com o filósofo contemporâneo Foucault (1995), posturas pautadas na temperança e na ética, visto que, essas são características inerentes à condição de ser político. Para o filósofo, político é aquele sujeito que tem o domínio da capacidade de cuidar de si como condição que o habilita para cuidar do outro, sendo a temperança e a ética requisitos obrigatórios para a conquista dessa condição. No entanto, a história da humanidade vem revelando que as sociedades, quando da escolha dos seus representantes, deixaram de se guiar por esses princípios.

Essas polêmicas declarações proferidas pelo chefe da nação brasileira estamparam capas de matérias jornalísticas diante da relativização da situação pandêmica que já estava configurada no país e das acusações aos noticiários da mídia brasileira e a chefes de outros entes federativos que, em oposição à postura do presidente, estavam decretando situação de calamidade pública em seus estados e municípios:

Presidente Jair Bolsonaro - Brevemente o povo saberá que foi enganado por esses governadores e por grande parte da mídia nessa questão do coronavírus. Espero que não venham me culpar lá na frente pela quantidade de milhões e milhões de desempregados na minha pessoa [...]. Não podemos politizar isso aqui, só falei isso porque eles me atacam constantemente [...]. A grande mídia, governadores, de olho na minha cadeira, se puder antecipar minha saída, eles farão isso aí, mas da minha parte não terão oportunidade disso, nós vamos continuar nosso papel [...]. Mais importante que a economia é a vida. Mas, nós não podemos extrapolar na dose, com o desemprego aí, a catástrofe será maior [...]. Eu não trabalho com projeções de números, não interfiro no trabalho do Luiz Madetta, nosso ministro da saúde, eu vejo os números que partem de lá, dessas projeções, e tô achando que há um exagero nisso daí [...]. No momento, a minha grande preocupação é com a vida das pessoas, bem como com o desemprego que é proporcionado por esses governadores irresponsáveis [...]. A recomendação é ter calma, tranquilidade, não levar pânico à população, não exterminar empregos, senhores governadores, sejam responsáveis [...]. No momento já temos um problema, os governadores são os verdadeiros exterminadores de emprego. Parte dos governadores, deixo claro, estão exterminando empregos no Brasil. Essa é uma crise muito pior do que o próprio coronavírus vem causando no Brasil e pode causar ainda [...]. Tem uma comunidade no Rio de Janeiro, não vou falar o nome porque vão falar que estou discriminando, que tem um número de tuberculosos muito alto. Entrando o vírus lá, com toda certeza nessa comunidade, vai ter muita gente que vai perder a vida [...]. Tá havendo uma histeria (SALDAÑA, Folha de São Paulo, 2020). 
Nesse ínterim, segundo o Portal de Notícias G1 (2020):

Secretarias estaduais de Saúde contabilizam 1.629 infectados em todos os estados do Brasil. Último balanço oficial do Ministério da Saúde aponta 1.546. Foram registrados 25 mortos no país, 22 deles no estado de SP [...]. O Ministério da Saúde declarou, na sexta-feira (20), que todo o território nacional está sob o status de transmissão comunitária do coronavírus Sars-Cov-2, responsável pela pandemia da doença Covid-19. O ministro da Saúde, Luiz Henrique Mandetta, sinalizou no mesmo dia que a previsão é que os casos da doença disparem em abril e que o sistema de saúde entre em colapso. A transmissão comunitária ou sustentada é aquela quando não é possível rastrear qual a origem da infecção, indicando que o vírus circula entre pessoas que não viajaram ou tiveram contato com quem esteve no exterior.

Ou seja, as declarações do presidente da república de que a questão da disseminação do novo Coronavírus no Brasil se tratava de uma histeria, não se sustentava nos dados apresentados, inclusive, quando considerava que o Brasil se apresentava como o $2^{\circ}$ país com mais casos de contaminação pelo novo Coronavírus da alta cúpula do governo, levando o presidente à realização de dois testes para a detecção da doença. O país também se enquadrava como o $2^{\mathrm{o} 4}$ no mundo com o maior número de pessoas contaminadas. Assevera-se que, esse mesmo presidente, desrespeitando as recomendações da OMS e do Ministério da Saúde no sentido de evitar aglomerações e contatos sociais próximos, costumeiramente passou a aglomerar-se com populares em manifestações de apoio ao seu governo, contrárias ao regime democrático, às instituições de estado como o parlamento e o judiciário, bem como, aos meios de comunicação.

Mas, para além de uma questão política, o que apreendemos é que a pandemia do novo Coronavírus, um problema de natureza sanitária, colocou em evidência a ideia de inseparabilidade entre as dimensões históricas, sociais, culturais, econômicas, ambientais, científicas e tecnológicas como caminho estratégico para a efetividade de qualquer política pública empenhada na solução do problema.

Considerar a dimensão histórica significa retornar ao princípio originário da doença, ou seja, à constante relação de maus tratos do homem para com outras espécies animais, o que potencializou, na história da humanidade, a transmissão de doenças como a Síndrome respiratória aguda grave (SARS), provocada por gatos de rua na China, e a Influenza A (gripe suína) ocasionada por grupos de porcos confinados no México, as quais são apenas dois exemplos da perversidade humana que resultou na transmissão de doenças de animais para pessoas e, consequentemente, de pessoa para pessoa.

Implica político e socialmente, como já abordamos, em questões partidárias, ideológicas e de poder em contraposição a um quadro social de vulnerabilidades socioeconômicas, déficits habitacionais e inóspitas condições sanitárias, de moradia e ambientais, às quais, grande parcela da população brasileira está submetida.

Perpassa social e tecnologicamente pela nossa natureza humana de seres coletivos, logo, não isolados e, ao mesmo tempo, vislumbrados por uma cultura digital que afetou significantemente as nossas maneiras de nos relacionarmos e os nossos modos de vida, criando a falsa ilusão seres autossuficientes, que se bastam por si só e/ou por suas materialidades.

Mas, principalmente, a pandemia do novo Coronavírus traz à tona os paradoxos do progresso: ao mesmo tempo em que atingimos um grau de inovação tecnológica surpreendente que levou à consolidação de uma "sociedade em rede", o fato da fluidez das fronteiras físicas e da interdependência política, cultural,

\footnotetext{
${ }^{4}$ Segundo o Painel Coronavírus acessível no site do Ministério da Saúde do Brasil, o país até o dia 22/06/2020 acumulava 1.106 .470 casos conformados, sendo 571. 649 recuperados, $483.550 \mathrm{em}$ acompanhamento e 51.271 óbitos acumulados e confirmados, cuja taxa de letalidade é de $4,6 \%$.
} 
econômica, científica, tecnológica e ambiental inerentes a esse modelo de sociedade, são os fatores que mais dificultam a efetividade desse isolamento tido como principal estratégia para o controle da disseminação de um vírus com grau significativo de letalidade a determinados grupos sociais e que ainda não possui vacina para a sua prevenção.

Buscar compreender essa pandemia relacionando-a às dimensões que a envolvem, nos instiga a refletirmos sobre a ideia de progresso, a natureza social humana, a liquidez e a virtualização das relações sociais, bem como, os choques e as diferenças entre culturas distintas, mas também nos instiga a pensarmos sobre a impossibilidade real de se isolar num mundo glocal ${ }^{5}$, sem fronteiras de circulação e de interdependência política, cultural, econômica, científica, tecnológica e ambiental. Ainda, nos faz a voltar os olhos para aqueles sujeitos que, por condições socioeconômicas desfavoráveis, questões raciais, físicas e de gênero sempre estiveram isolados. Quando olhamos para contextos sociais de extrema vulnerabilidade socioeconômica em que, segundo dados atualizados pelo Instituto Brasileiro de Geografia e Estatística (IBGE), 11,6 milhões de pessoas estão desempregadas, mais de 101 mil pessoas vivem nas ruas em todo o Brasil e mais de 13,5 milhões de famílias estão em situação de extrema pobreza não dispondo sequer de água tratada, condições sanitárias, moradia e/ou abrigos minimamente dignos, constatamos que o isolamento para essas pessoas, sob as suas mais variadas formas, sempre foi uma realidade. Com isso, não é precipitado dizer que ao término dessa pandemia do novo Coronavírus, os maiores percentuais de vitimados letais pela Covid-19 serão, justamente, essas pessoas.

Dizer que o mundo parou, à luz dessas reflexões, traz em si a ideia de que a pandemia do novo Coronovírus parou nossos corpos no sentido filosófico da expressão com a finalidade de movimentar os nossos pensamentos, ou seja, nos provocou a (re)pensarmos na interdependência das dimensões que constroem as sociedades.

Essa pandemia, ao mesmo tempo, nos desvela a certeza de que somos seres dependentes do outro, que não nos bastamos por nós mesmos, precisamos do outro para viver, para tomarmos consciência de si, haja vista que, conforme Foucault (1995), é a tomada de consciência que nos transforma e que nos permite transformar, em síntese, o cuidado com o outro implica num autocuidado, numa preocupação não egocêntrica com a vida.

Portanto, a busca por respostas às questões, que aqui levantamos, nos leva a (re)pensarmos os atributos inerentes a uma "modernidade líquida", os quais, paradoxalmente, estão vinculados à noção daquilo que idealizamos por chamar de progresso e/ou visão de futuro. Elas nos possibilitam a tomada de consciência da nossa pequenez de seres autossuficientes, da sensibilização com o outro (alteridade). Por último, possibilitam que rompamos com a ilusão de que somos a razão da nossa própria existência, tendo em vista que, ela é resultante de um processo que articula interioridades e exterioridades.

\section{Para um desenlace de conversa}

Iniciamos este artigo com a análise de uma sentença filosófica para adentrarmos na sua relação com uma crise mundial que, além de sanitária, revelou-se econômica, política, científica e cultural, ou seja, uma crise híbrida do ponto de vista geopolítico e, dessa forma, o concluímos.

\footnotetext{
${ }^{5}$ De acordo com Giddens (1995, p. 52), a glocalização é definida "como a intensificação das relações sociais à escala mundial, relações que ligam localidades distantes de tal maneira que as ocorrências locais são moldadas por acontecimentos que se dão a muitos quilómetros de distância".
} 
Assim como Bernardo (2005) problematiza a sentença do filósofo René Descartes - Dubito ergo sum, vel quod item est, cogito ergo sum - interpretando-a como "duvido, logo existo" que, semanticamente, extrapola um imediatismo explícito na sentença "penso, logo existo", acreditamos que devemos duvidar do aparente ineditismo tecnológico em torno de uma "modernidade liquida" propiciadora da "sociedade em rede" altamente alterada pelo "meio técnico-científico-informacional" como se fosse o único caminho para se alcançar o progresso.

Por isso, ao crivo da dúvida, é que analisamos a frase "o mundo parou" para além de uma perspectiva meramente cartesiana, visto que, nesse modelo de "sociedade em rede", conforme desvela Nietzsche (1993), o pensamento nem sempre é causado pelo sujeito que o (re)produz.

Uma análise sintático-exata da frase "o mundo parou" com base na transitividade do verbo parar" nos leva a classificá-lo como intransitivo, visto que, o seu significado está completo, não requer um objeto, ou seja, a sua ação inicia e termina no sujeito - o mundo. A sua análise sintática nos leva a entender que o mundo quem deixou de se movimentar, deslocar, progredir, pois o sujeito da frase de sentido intransitivo é o mundo.

Entretanto, uma análise duvidosa dessa frase nos permite analisar o verbo parar como demandante de um complemento, quer seja objeto direto, quer seja objeto indireto. Nos permite questionar quem é esse sujeito, "o mundo", somos nós? Nos permite, ainda, afirmar que, a depender de quem seja o sujeito, parar pode ser lido como movimento, sobretudo, num contexto de "sociedade em rede", cujas relações sociais e maneiras de vida são tão líquidas, aceleradas e automatizadas, que se faz necessário parar para que elas aconteçam, movimentem-se, progridam e sejam.

Em uma perspectiva de análise a partir da dúvida, entendemos o verbo parar como um devir, voltar para dentro de si após ter ido, como ação, dinâmico e não estático. Em outras palavras, um movimento de parar a atenção para a alienação tecnológica que se vive, o distanciamento com a sua essência humana e o vínculo com o outro, como forma de (re)significar o autoconhecimento e as relações sociais. Parar, nesse sentido, é movimento e não inércia.

Parar, enquanto movimento e no contexto pandêmico do qual nos valemos como pano de fundo, seria uma possibilidade de nos movimentar a (re)pensar respostas para questões que surgem das dimensões sociais, histórias, culturais, políticas, econômicas, ambientais, científicas e tecnológicas que explicam o contexto crítico atual. Por outo lado, do ponto de vista de um economicista, por exemplo, o verbo parar na frase em análise será sempre intransitivo remetendo à ideia de uma economia inerte, sem movimento, sem deslocamento e, portanto, contrária à concepção de progresso no sentido restritamente econômico da palavra.

Contudo, algo nos é indubitável nesta conclusão: “o homem é um animal social”, quer seja pela via da lógica aristotélica, quer seja pela via da fenomenologia hegeliana. Somos em todo tempo e em qualquer espaço seres sociais por natureza, temos a necessidade de interação com o outro, mas não qualquer tipo de interação, precisamos daquela que, como caracteriza Levy (2000, p. 107), nos liga em "carne e osso".

Por fim, concluímos que essa natureza humana, que deveria ter sido radicalizada a sua potência máxima com a tecnologia, subverteu-se, visto que, virtualizamos as nossas relações, deixamos de ser reais, de "carne e osso", tomamos gosto pela virtualidade típica de uma "sociedade em rede" numa "modernidade líquida" alterada pelo "meio técnico-científico-informacional".

\footnotetext{
6 De acordo com Dicionário Houaiss da Língua Portuguesa (2001), o verbo "parar" pode ser classificado como transitivo direto, transitivo indireto e intransitivo.
} 
Mas, se o que caracteriza a condição de ser humano é a presença dessa sua natureza social, teríamos perdido o humano com a virtualização?

Pelo contrário, a capacidade de virtualidade possibilita que o humano exista, viva. Vida, por sua vez, é o devir, o vir a ser, o que se transforma. No entanto, percebemos nessa "sociedade em rede" uma ideia de desvalorização da vida, de negação do corpo, da presença e do instante e isso não é, definitivamente, responsabilidade de uma sociedade tecnológica. A virtualização das relações, a falta de corpo tem uma origem cultural que é, tão somente, intensificada pelo "meio técnico-científico-informacional”.

E de que cultura estamos falando? Da que é imposta por um poder ou daquela que resulta de uma criação humana?

Certamente de uma cultura imposta, especialmente quando a relacionamos com as complicações de um contexto pandêmico viral, que se caracteriza como uma crise com poucos precedentes na história da humanidade. Esse contexto é um desestabilizador da ideia dominante de cultura de seres virtuais, autossuficientes, sociedades dominantes e invencivelmente poderosas, evidenciando que ela é mais uma imposição social como atributo necessário para a perpetuação de uma "modernidade líquida" demandante da existência de subservientes culturais do que, de fato, aquilo que entendemos por cultura: uma criação humana para servir à nossa condição de humanos.

\section{Referências}

AQUINO, Tomás de. (1994). Suma de Teología I. Trad. BAC. 2. ed. Madrid: BAC. t.1.

ARENDT, Hannah. (2001). A condição humana. 10. ed. Trad. Roberto Raposo. Rio de Janeiro: Forense Universitária.

ARISTOTE. (1982). La politique. Tradução de J. Tricot. Paris: Vrin.

BAUMAN, Zygmunt. (2001). Modernidade líquida. Rio de Janeiro: Jorge Zahar.

BERNARDO, Gustavo. (2005). “A qualidade da invenção”. In: OLIVEIRA, leda de. O que é qualidade em literatura infantil e juvenil? Com a palavra o escritor. São Paulo: DCL.

BOtTOMORE, T. (1998). Dicionário do Pensamento Marxista. Rio de Janeiro: Jorge Zahar Editor.

BRASIL. Ministério da Saúde. (2020). Painel Coronavírus. Disponível em: https://covid.saude.gov.br/. Acesso em: 22 jun. 2020.

CASTELLS, Manuel. (1999). A sociedade em rede. São Paulo: Paz e Terra.

DESCARTES, René. (1973). “Discurso do método, meditações, objeções e respostas, as paixões da Alma e Cartas”. Introdução de Gilles-Gaston Granger; prefácio e notas de Gérard Lebrun. Trad. Guinsburg e Bento Prado Júnior. Editor Victor Civita. São Paulo: Editora Abril Cultural.

FOUCAULT, Michael. (1995). “O sujeito e o poder”. In: P. RABINOW e H. DREYFUS, Michel Foucault: uma trajetória filosófica (para além do estruturalismo e da hermenêutica). Rio de Janeiro: Forense Universitária.

GIDDENS, Anthony. (1995). As consequências da modernidade. Oeiras: Celta Editora.

HABERMAS, Jürgen. (1968). Técnica e espaço como ideologia. Título original: Technick und 
Wissenschaft als «Ideologie». Tradução de Artur Morão. Suhrkamp Verlag, Frankfurte am Main, HEGEL, Georg Wilhelm Friedrich. (1992). Fenomenologia do Espírito. Trad. de Paulo Meneses e Karl-Heinz Efken. Petrópolis: Ed. Vozes.

HOUAISS. (2001). Dicionário da língua portuguesa. Rio de Janeiro: Objetiva.

IBGE - Instituto Brasileiro de Geografia e Estatística. (2020). Divulgação de indicadores. Acessado em 20/03/2020 e encontrado em https://www.ibge.gov.br/calendario-indicadores-novoportal.html.

JENKINS, Henry. (2009). "Introdução": Venere no Altar da Convergência: um novo paradigma para entender a transformação midiática. In: A cultura da convergência. Trad. Susana Alexandria. 2.ed. São Paulo: Aleph.

LEFEBVRE, Henri. (1985). A produção do espaço. Trad. Doralice Barros Pereira e Sérgio Martins (do original: La production de l'espace. 4e éd. Paris: Éditions Anthropos, 2000).

LEVY, Pierre. (2000). “O Ciberespaço ou a Virtualização da Comunicação”. In: LEVY, Pierre. Cibercultura. Trad. Carlos Irineu da Costa. 2.ed. São Paulo: Ed.34.

LYOTARD, Jean-François. (2004). A Condição Pós-Moderna. Rio de Janeiro: José Olympio.

NIETZSCHE, Friedrich Wilhelm. (1993). “Vom Ursprung der Sprache”. In: Nietzsche Werke. Kritische Gesamtausgabe (org. Fritz Bornmann). Abteilung II, Band II. Vorlesungsaufzeichnungen (SS 1869 - WS 1869-1870). Berlin/New York: Walter de Gruyter.

NIETZSCHE, Friedrich Wilhelm. (1999). "Curso de retórica”. Cadernos de tradução. n. 4, São Paulo: Edusp.

OMS - Organização Mundial da Saúde. (2020). Folha informativa - COVID-19 (doença causada pelo novo coronavírus), 2020. Acessado em 22/03/2020 e encontrado em https://www.paho.org/ bra/index.php?option=com_content\&view=article\&id=6101:folha-informativa-novo-coronavirus2019-ncov\&ltemid=875.

PINTO, Álvaro Vieira. (2005). O conceito de Tecnologia. Rio de Janeiro: Contraponto.

PORTAL DE NOTÍCIAS G1. (2020). Casos de coronavírus no Brasil em 23 de março. Acessado em 23/03/2020 e encontrado em: https://g1.globo.com/bemestar/coronavirus/noticia/2020/03/ 23/casos-de-coronavirus-no-brasil-em-23-de-marco.ghtml.

PORTAL DE NOTÍCIAS G1. (2020). E daí? Lamento. Quer que eu faça o quê?', diz Bolsonaro sobre mortes por coronavírus; 'Sou Messias, mas não faço milagre. Acessado em 19/05/2020 e encontrado em https://g1.globo.com/politica/noticia/2020/04/28/e-dai-lamento-quer-que-eu-faca-oque-diz-bolsonaro-sobre-mortes-por-coronavirus-no-brasil.ghtml.

PRADO, Adriana. (2020). "Revista Isto é”. Zygmunt Bauman “Vivemos tempos líquidos. Nada é para durar. Acessado em 18/03/2020 e encontrado em https://istoe.com.br/102755_vivemos+tempos+liquidos+nada+e+para+durar+/.

SALDAÑA, Paulo. (2020). "Revista Folha de São Paulo”. Em entrevista, presidente voltou a acusar chefes estaduais de politizar combate à Covid-19. Acessado em 22/03/2020 e encontrado em 
https://www1.folha.uol.com.br/poder/2020/03/povo-sabera-que-foi-enganado-por-governadores-e-imprensa-sobre-coronavirus-diz-bolsonaro.shtml.

SANTOS, Milton. (1997). A natureza do espaço. São Paulo: HUCITEC.

SANTOS, Milton. (2008). Técnica, Espaço, Tempo: Globalização e Meio técnico-científico-informacional. 5. ed. São Paulo: Editora da Universidade de São Paulo.

SANTOS, Milton. (2009). A Urbanização Brasileira. 5. ed. 2. São Paulo: Editora da Universidade de São Paulo.

Artigo recebido em: 20 de maio de 2020

Artigo aceito em: 17 de julho de 2020 